\title{
SYSTEMS APPROACH: CLIMATE CHANGE, GLACIER MELT AND DEVELOPMENT PLANNING OF THE HIMALAYAN REGION
}

\author{
Sakkeri Ramya, Indian Institute of Technology Roorkee, India \\ Prof. V. Devadas, Indian Institute of Technology Roorkee, India
}

\begin{abstract}
Experience over the last decade has demonstrated a gradual rise in global temperatures, which coupled with the unpredictable precipitation patterns (rainfall \& Snow/ glacier melt are considered as important hydrologic process in the Himalayan basins), are expected to seriously affect the melt characteristics and further increase pressure on available water resources (both quantity and quality). The situation is being exacerbated intensified by the increasing water demands from agriculture, industry and rising population. However, current investigations reveal that there is a lack of a general framework for assessment. The major responsibility of the planning community is to adopt rational planning approach addressing the complexity of the system, yet it is appearing that the models used at various stages are not well developed to keep the same pace. This demands the acknowledgment and a better understanding of the dynamic inter-linkage and interdependence of the complex systems and sub-systems (namely physical, social, economic, ecology, environment, infrastructure, and institutional subsystems) using system dynamics technique.

The aim of this paper is to develop a methodology for assessing the climate change and its impact on a region by demonstrating the inadequacy of sectoral and silobased planning approaches to address the complex sustainable development challenges whose interdependencies and inter-linkages transcend individual sectors and administrative borders. Further, this paper attempts to present the review of research done on the use of an integrated approach by using system dynamics technique in the context of evolving development plans. It concludes with extending the knowledge to support climate change adaptation and mitigation decisions to achieve sustainable development at the regional scale.
\end{abstract}

\section{Keywords}

System dynamics, Sustainable development, Engineering village, Water resources

\section{Introduction}

As per Inter Governmental Panel on Climate Change Assessment Report (2007) , more than $1 / 6$ th of world population depend on snow-melt or glacier fed rivers and the galciers are expected to continue to melt as the temperature rise. Changes in recent climate and associated impacts on natural and human systems have been reported widely (IPCC, 2014; Azhoni, Jude and Holman, 2018). Himalayan glaciers are sources of freshwater reserves providing headwaters for 10 major river systems in Asia - a lifeline for almost one third of 
humanity. Glaciers supply freshwater to 500 million people in Himalaya- Hindu- Kush region and 250 million people in China (IPCC). The system of water resources for sustainable development is a large, complex and nonlinear system and development of social economy can be seriously restricted by potential shortage of water resources (Winz, Brierley and Trowsdale, 2008; Chen and Wei, 2014). The situation is being exacerbated intensified by the increasing water demands for agriculture, industry and rising population. However, current investigations reveal that there is a lack of a general framework for assessment.

The present review paper aims to consolidate the state of the art in climate change, glacier melt and development panning. This study identifies the key knowledge gaps for successful implementation of adaptation strategies. This review paper brings together current literature on climate change, glacier melt and applications of system dynamics with the aim of identifying characteristics that enable decision makers in sustainable development planning of a region. It is divided into five sections. Section 1 has identified the need for consolidating the current knowledge on climate and argues the relevance of this review in the current discourse on climate change adaptation particularly for sustainable development. After the brief introduction to the aim and significance of the review in Section 1, Section 2 brings together the current status of literature. Section 3 identifies the remaining gaps in the empirical literature. Section 4, framework to achieve sustainable development is discussed in detail. Finally, conclusions are drawn with key climate change mitigation and adaptation measures in Section 5.

\section{Current state of the literature}

The authors performed a systematic analysis of literature on Climate change, glacier melt and development planning (Figure 1), through the following steps: (i) Search for scientific publications on the Engineering Village platform (COMPENDEX and INSPEC) using a set of key words, such as System dynamics; Climate change, and Controlled terms as Water resource; Sustainable development; Planning; (ii) Initial search resulted 2,04,377 records (excluding duplicates) between the years 1884 and 2020, including all document types viz., Journal articles, conference proceedings, dissertations, etc., (iii) Later, to avail the most updated literature on this subject the search was limited to past decade, i.e., between 2009 and 2018, including 1,43,387 records; (iv) further, the authors conducted a search limiting to journal articles only $(66,417$ records), as they represent a more mature research on this subject with stronger methodological background; $(v)$ To refine the results the search was limited based on controlled vocabulary, such as socio-economic effects, environment factors, climate mitigation, glacier melt; (vi) Content analysis of 614 article abstracts was conducted to validate whether it focused on the role of system dynamics in the sustainable development process, as well as identify the dimension( or dimensions) it is centered on. The authors read full text when in doubt in order to understand its focus; (vii) Exclusion of articles that do not focus on the subject (208 records were excluded) (viii) Categorization of literature (406 records) was done based on focus sector based linkages involved in climate change resilient/sustainable development planning process; (ix) Informetric analysis of literature for 406 records was conducted to observe the trends in literature, identify top journals (Figure 3), determine classification code based on word frequency (Figure 3), and analyse the dispersion of articles in previous years and also with respect to publishers Figure 3. For this purpose, authors employed a software, the VOSviewer, which is often used in 
bibliometric, scientometric, and informetric studies; $(\mathrm{x})$ Critical analysis according to defined categories; Currently, the bibliometric, scientometric and informetric analysis are the three main metrics to quantitatively analyze the scientific literature (Qiu, J., R. Zhao, S. Yang, 2017). Santos et al., (2019) explains that bibliometric analysis focuses on the quantitative analysis of the published articles, such as, number of publications per year. On the other hand, scientometric studies quantify the researchers' achievements, such as citation analysis. In contrast to the aforementioned, the purpose of informetric analysis is to obtain additional information, such as word frequency and dispersion of literature.

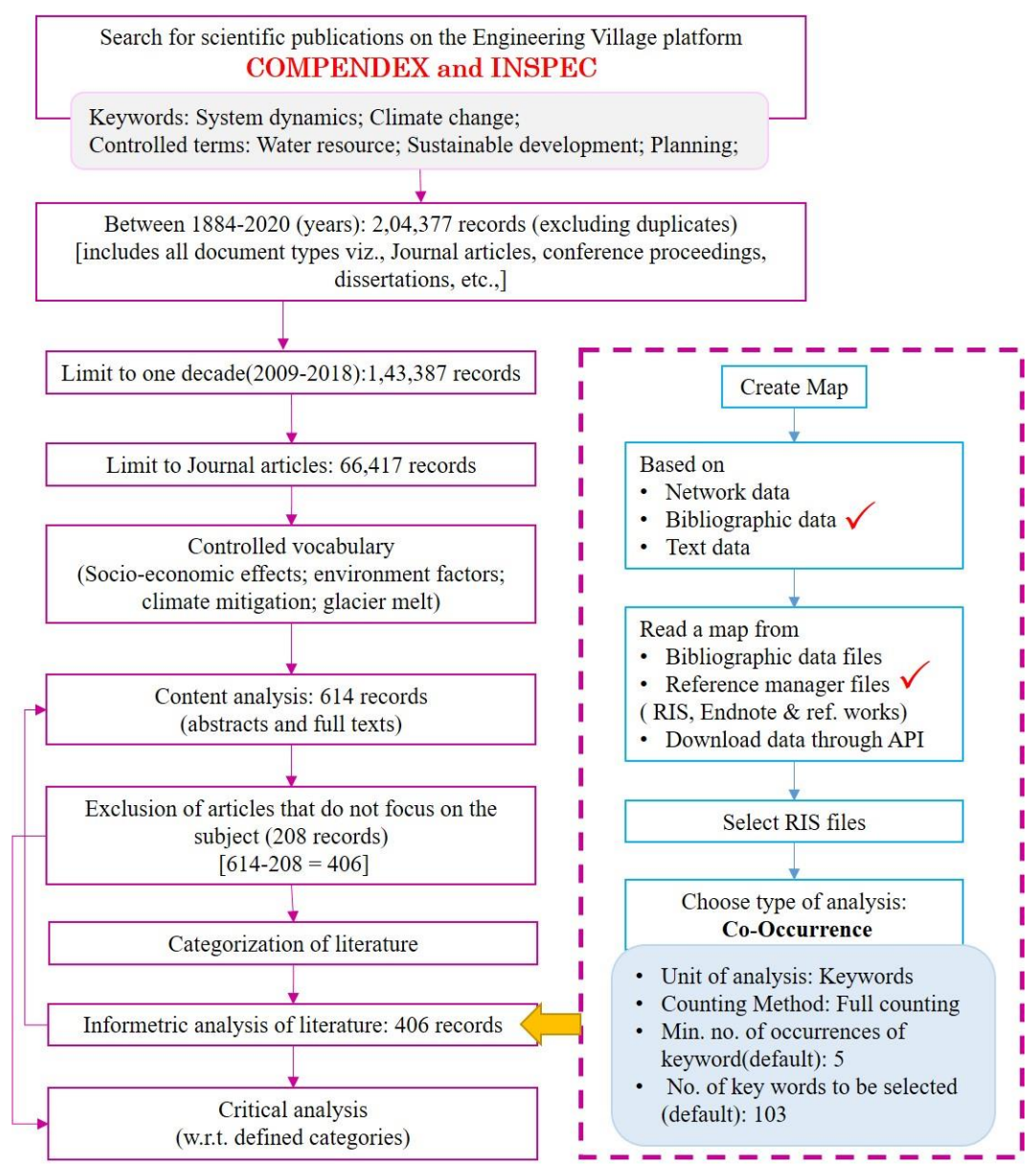

Figure 1: Methodology adopted for a systematic analysis of literature on sustainable development planning and system dynamics

In this study, informetric analysis as carried for the 406 records that are obtained after exclusion of articles that do not focus on subject. The information obtained from informetric analysis was later validated by a content analysis, in which gaps and trends were identified. It is observed that the articles are largely concentrated on the three major pillars of sustainable development, such as environment, economic and social dimensions. However, it is important to note that there is a possibility that an article can fall under more than one category too (Figure 2). Further, it is observed that publications on this subject registered an exponential growth, with $77.5 \%$ of the articles being published in the last five years (Figure 2). A total of 1308 authors were identified contributing for 406 published articles. As high as 60 articles are from Journal of cleaner production followed by sustainability with 52 articles, energy policy with 12 articles (Figure 3). Also, Elsevier publications accommodates for $34 \%$ of the total articles reviewed and is followed by Emerald, MDPI, Springer, Wiley, etc., (Figure 3). 
The articles largely focused keywords (top 5) are socio-economic effects, sustainable development, environment factors, climate mitigation and government policies (Figure 4).Lastly, Figure 5 shows the network analysis and cluster analysis of the top words used by the authors in the Keywords.
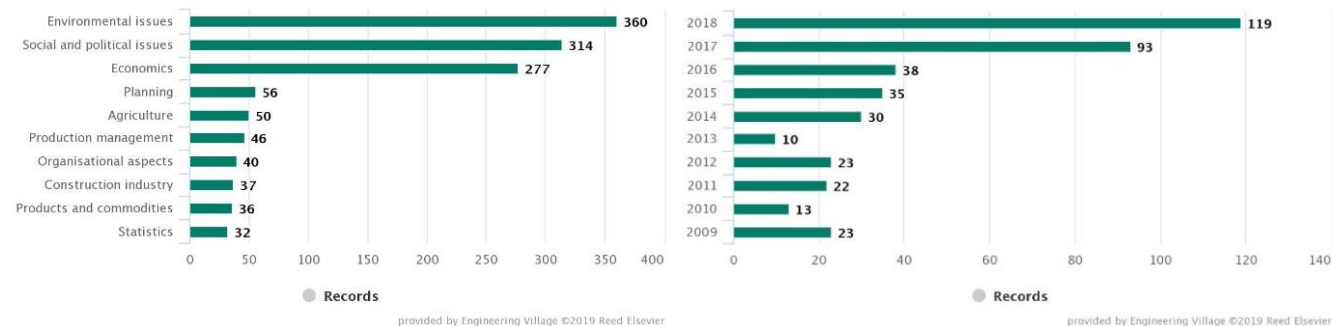

Figure 2:Graph showing articles count based on classification code (left) and year of publication (right)
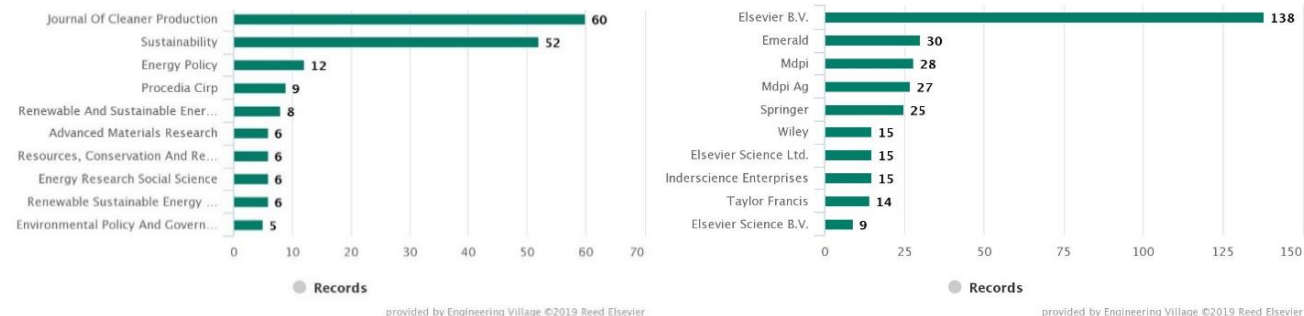

Figure 3:Graph showing articles count based on journal title (left) and publisher (right)

\begin{tabular}{|c|l|r|r|}
\hline \multicolumn{1}{|c|}{ Keyword } & Occurrences & \multicolumn{2}{c|}{$\begin{array}{c}\text { Total link } \\
\text { strength }\end{array}$} \\
\hline$\square$ & socio-economic effects & 406 & 898 \\
\hline$\square$ & sustainable development & 393 & 884 \\
\hline$\square$ & environmental factors & 306 & 675 \\
\hline$\square$ & climate mitigation & 127 & 313 \\
\hline$\square$ & government policies & 72 & 224 \\
\hline & & & \\
\hline
\end{tabular}

Figure 4: No. of Occurrences and total link strength of top 5 keywords identified

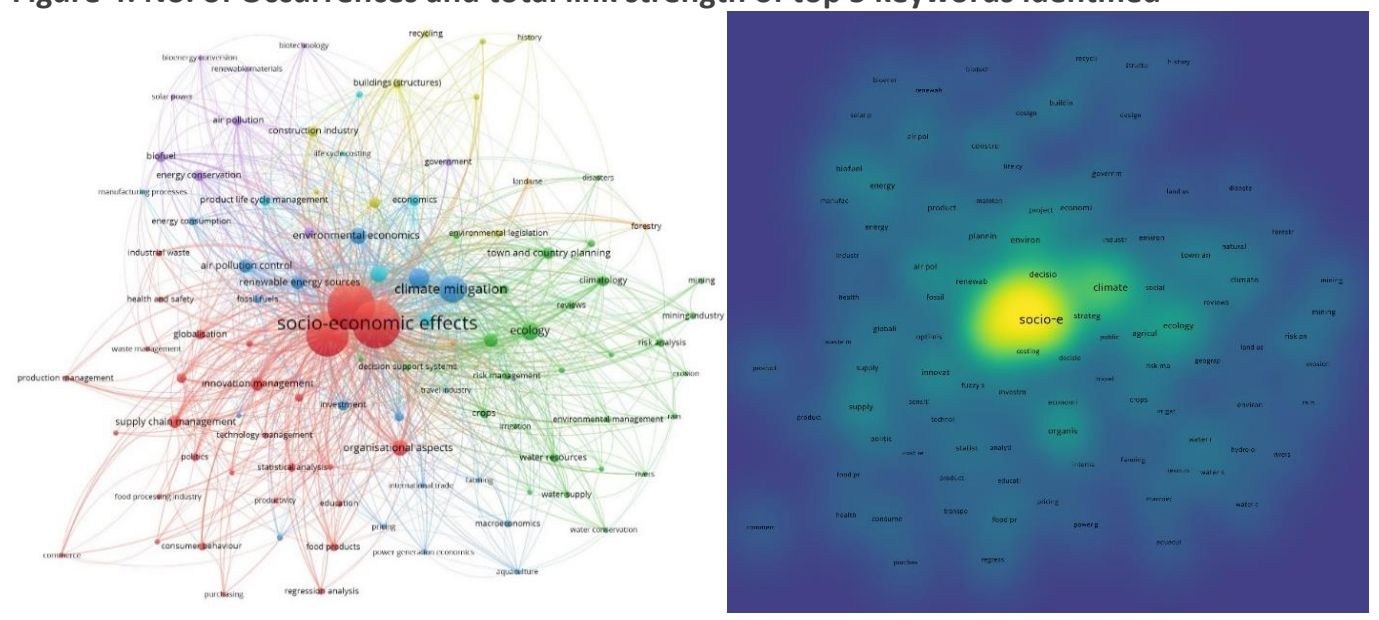

Figure 5:Network analysis (left) and cluster analysis (right) of the top words used by the authors in the Keywords. 


\section{Remaining gaps in the empirical literature}

Climate change has been the focus of much research and analysis for more than a decade now. However, it is observed that the difficulties still exists in understanding the major processes of climate change despite the considerable knowledge of the broad characteristics of the climate. Despite the global implications of the problem, the overwhelming majority of the researchers involved worldwide in studying the problem and its possible solutions are from industrialized countries, and participation of lesser-industrialized countries has been limited (Kandlikar and Sagar, 1999).

According to Miller, Stumm and Stoffel (2012), "Glaciers across the region are generally shrinking but regional and temporal variation exists, and there is little to corroborate statements pertaining to accelerated rates of melt". This research is under taken to draw a defining line under such statements and set the research objectives towards better understanding the processes driving this melt, how climate forces change, and the potential impacts of increased / reduced melt water from glaciers and snow on future water resources under climate change scenarios. This compels climate change researchers not only to study each individual component of the climatic system but also focus on integrated modelling approach to enhance significant advances in understanding the indefinable and complex process of climatic change that enables the future planning initiatives within the region to consider the inter relationships among all the sub systems (seven) that could play a key role in achieving sustainable development.

The comprehensive study of literature reveals that researches have been conducted in the field of sustainable development planning by considering only one or two subsystems, and lack an integrated approach, which considers all seven subsystems of the system together. Some of the key recent studies done by various researchers /organizations are discussed here (Table 1). Also, the authors identified a gap in literature pertaining to the integration of the climate change, Glacier melt, water resource management and sustainable development planning by using system dynamics technique; however, literature on the aforementioned has grown considerably in recent years, which indicates that system dynamics technique is increasingly being used as a reliable method for sustainable development practices.

\section{Framework to achieve sustainable development}

Framework for development plan formulation by using system dynamics technique has been developed based on rational planning approach (Figure 6). System dynamics is a method of learning complex processes. System dynamics approach considers holistic view to analyze the functional aspect through the spread and backwash effects in all sub-systems of the system. Sterman (2000) states that System Dynamics is fundamentally interdisciplinary and is concerned with the behaviour of complex systems. System dynamics is grounded in the theory of nonlinear dynamics and feedback control developed in mathematics, physics, and engineering. As these tools are used to understand the behaviour of human as well as physical and technical systems, system dynamics draws on cognitive and social psychology, economics, and other social sciences. Also, system dynamics models are built to solve important real world problems. 
Table 1: Focus of studies according to type of linkage and identification of the research gap from the literature reviewed

\begin{tabular}{|c|c|c|c|}
\hline Type of Linkage & Focus of Studies & Sources & Research Gap \\
\hline $\begin{array}{l}\text { Impact of climate } \\
\text { change on glaciers }\end{array}$ & Glacier Melting and Growing Crises & $\begin{array}{l}\text { (Singh and Singh, 2013);(Kaltenborn, Nellemann and Vistnes, } \\
\text { 2010);(Miller, Immerzeel and Rees, 2012);(Chandrappa, Kulshrestha and } \\
\text { Gupta, 2011) }\end{array}$ & \multirow{11}{*}{$\begin{array}{l}\text { An Integrated } \\
\text { Approach } \\
\text { considering } \\
\text { these linkages }\end{array}$} \\
\hline \multirow{3}{*}{$\begin{array}{l}\text { Impact of climate } \\
\text { change/ glacier } \\
\text { melting on water } \\
\text { resources }\end{array}$} & $\begin{array}{l}\text { Integrated regional water management planning; assessing } \\
\text { regional vulnerabilities and measuring regional impacts }\end{array}$ & (CDM, 2011); (Sharma and Sharma, 2008); & \\
\hline & Rainfall, temperature and catchment hydrological responses & $\begin{array}{l}\text { (Watts et al., 2015); (Rajesh Bhakar, 2012);(Jansson, Hock and } \\
\text { Schneider, 2003);(Prasad et al., 2009);(Zeng and Cai, 2014);(Miller, } \\
\text { Immerzeel and Rees, 2012) }\end{array}$ & \\
\hline & Evaluation of Snow melt Runoff & $\begin{array}{l}\text { (Panday et al., 2014);(Singh and Jain, 2003);(Fujita and Sakai, } \\
\text { 2014);(Duethmann et al., 2015);(Omani, Srinivasan and Smith, } \\
\text { 2016);(Prasch, Mauser and Weber, 2013);(Khan et al., 2015);(Kumar, } \\
\text { Singh and Singh, 2007);(Arora, 2010); }\end{array}$ & \\
\hline \multirow{7}{*}{$\begin{array}{l}\text { Impact of water } \\
\text { resources on } \\
\text { sustainable } \\
\text { development of } \\
\text { the region }\end{array}$} & $\begin{array}{l}\text { Physical } \\
\text { (Climate, topography, landuse, soil type) }\end{array}$ & $\begin{array}{l}\text { (Rahman et al., 2015);(Nepal, Flügel and Shrestha, 2014);(Tadele and } \\
\text { Förch, 2007) }\end{array}$ & \\
\hline & $\begin{array}{l}\text { Social } \\
\text { (Demography, Health, Education, Occupation, Culture/customs) }\end{array}$ & (Cox, 1987);(Mittal, Tripathi and Sethi, 2008) & \\
\hline & $\begin{array}{l}\text { Economic } \\
\text { (Resources, GSDP/NSDP/Percapita income, Sectors of economy, } \\
\text { Finance) }\end{array}$ & $\begin{array}{l}\text { (Bajracharya, Shrestha and Shrestha, no date);(Kaltenborn, Nellemann } \\
\text { and Vistnes, 2010);(Singh and Pallavi, 2015); (Harender Raj Gautam, } \\
\text { 2012) }\end{array}$ & \\
\hline & $\begin{array}{l}\text { Ecology } \\
\text { (Flora \& Fauna) }\end{array}$ & --- & \\
\hline & $\begin{array}{l}\text { Environment } \\
\text { (Pollution, Water resources, Forestry) }\end{array}$ & --- & \\
\hline & $\begin{array}{l}\text { Infrastructure } \\
\text { Physical (Electricity, Water supply, Sewerage, Transport, Energy); } \\
\text { Social (Education Health, Recreational,etc) } \\
\text { Economy(Banks,co-operations, Markets/SEZ's); }\end{array}$ & $\begin{array}{l}\text { Physical: (Asian Development Bank, 2014); } \\
\text { Social:--- } \\
\text { Economy: --- }\end{array}$ & \\
\hline & $\begin{array}{l}\text { Institutional } \\
\text { (Local self-Government, DRDA, MoUD, Regional planning board, } \\
\text { MoEF, CWC, CPCB/SPCB, Planning Commission) }\end{array}$ & ---- & \\
\hline
\end{tabular}


Like many other disciplines, system dynamics has witnessed various changes in its philosophy, strategy, and technique, in the course of its ongoing evolution. In accordance to the problem statement or need of the study, the sub-systems considered in each case differs. The framework developed in this paper is an improvised version from its first application by one of the authors. He has employed System Dynamic technique in different doctoral research theses and masters' theses in supervision of one of the author's at Department of Architecture \& Planning, Indian Institute of Technology Roorkee and are presented as follows: Salim (2004) worked on Integrated development plan of Thiruvananthapuram City, Kerala with main focus on population; housing; health, education and energy sub-systems. Similarly, others like Das (2006) prepared Tourism development plan for Bhubaneshwar and Cuttack Region, Orissa by considering tourism and tourism related infrastructure as the catalyst for the development of the region, with focus subsystems as Population and population density; roads and its networks; railways; hotels and number of beds; land and land-use. Sonar (2006) worked with Information technology as the focus theme for Pune City, Maharashtra by considering sub-systems, such as population and population density; transportation (road lengths); power; commercial area; housing (household units); human resources; information technology industries. Zia (2007) in her work considered the Solid Waste Management (SWM) and required infrastructure for SWM as catalyst for the development of the Kanpur city. The sub-systems considered are: Population and population density; household waste generation, industrial waste generation, commercial and market waste generation, collection, transportation, treatment and disposal; environmental stress, infrastructure requirement in formal sector and manpower requirement in informal sector. Chauhan (2009) used optimal transportation system for the development of the city involving sub-systems, such as Population and population density, household vehicle ownership, residential-parks and playground transportation land-use, vehicular population, modal split and transportation demand. The work of Pipralia (2010) was based on hypothesis that optimal municipal financing management will deliver good services to the city. It was observed from the literature that no work was attempted by employing system dynamics in this line. Sub-systems considered for financial management of Jaipur city are: Population; domestic water supply; waste water; solid waste management, developed urban, residential area, road length and road density; infrastructure network and investment cost; urban finance. Kumari (2015) focused on regional development of Patna Region by increasing the standard of living, involving following sub-systems: Population and population density, sex ratio, literacy rate and IMR (infant mortality rate); area under HYV (high yielding variety) crop, net irrigated area, and rate for fertilizer consumption; electrification of villages, pollution level and road length; use of farm machinery and pesticides; production of cereals, pulses, vegetables, fruits, flowers, milk, egg, meat, fish; GDP from agriculture and allied activities, industrial sector; GDP and per capita income; and sector-wise planned and non-planned expenditure. Energy Management plan for Jaipur city was developed by Kumar (2016) by considering the optimal energy management as catalyst for the development of the system with sub-systems such as, Population, energy generation from sewage waste water, energy generation from municipal solid waste, energy generation from solar photovoltaic system, electricity consumption for domestic buildings, household domestic purpose, commercial purpose, industries, street lights, mixed usages, agriculture purpose, domestic cooking purpose, transportation, total registration of vehicles. Rawal (2016) worked on transportation system of Kanyakumari district by considering sub-systems such as: Population and vehicle growth 
model, road network gap index, road network capacity gap index, overall road network level of service, hierarchical road network level of service, GDP and employment, transportation investment, carbon emission gap, fuel consumption gap, transportation area unused or wasted, MSME, tourism growth, District attractiveness index. Land Management plan for Jaipur City was developed by Nigam (2016) using City development index and considered Population, land-use, housing, finance, tax collection, infrastructure (physical and economics), land related institutions, urban environment sub systems. Regional development plan for Lucknow city was developed by Gupta (2017) considering all three pillars of sustainable development concept. The sub-systems involved are Population, health index, education index, housing index, infrastructure index, land-use, crop production, livestock and milk production and horticulture.

The methodology developed in this paper involves stages as follows: Initially the problem is identified through either literature review or theories/concepts or by knowing the current condition/existing scenario of the region through various stakeholders and then a goal is formulated accordingly. Parameters concerning climate change, glacier melt, and sustainable development planning are thereby identified, and the quantitative and qualitative data for the identified parameters is collected by using primary and secondary surveys. Further, data analysis is carried out by applying analytical methods/ techniques that leads to identification of control parameters of the system (region). The identified control parameters are further distributed among seven sub-systems, namely, Physical, social, economic, ecology, environment, infrastructure and institutional. A qualitative/conceptual model is developed, which is represented in the form of causal-loop diagrams with a defined system boundary. Later, qualitative simulation model represented as stock flow diagram is developed by using the following stages: (1) Formulation of base year system dynamic model;(2) Model validation (evaluate and test model); (3) Evolving projected year system dynamic model; (4) Application of the model under different alternative conditions. Results obtained from the analysis are studied in detail, and in case the obtained results are unsatisfactory or contain any error then go to data analysis stage to rectify the error or change the analytical method/technique adopted in accordance to problem statement requirement. Once the results obtained are found satisfactory, then the findings are to be synthesised to evolve plausible solutions and implement the suggested recommendations. Finally, the key indicators/control parameters are tracked and the progress is evaluated in accordance with the problem statement. 


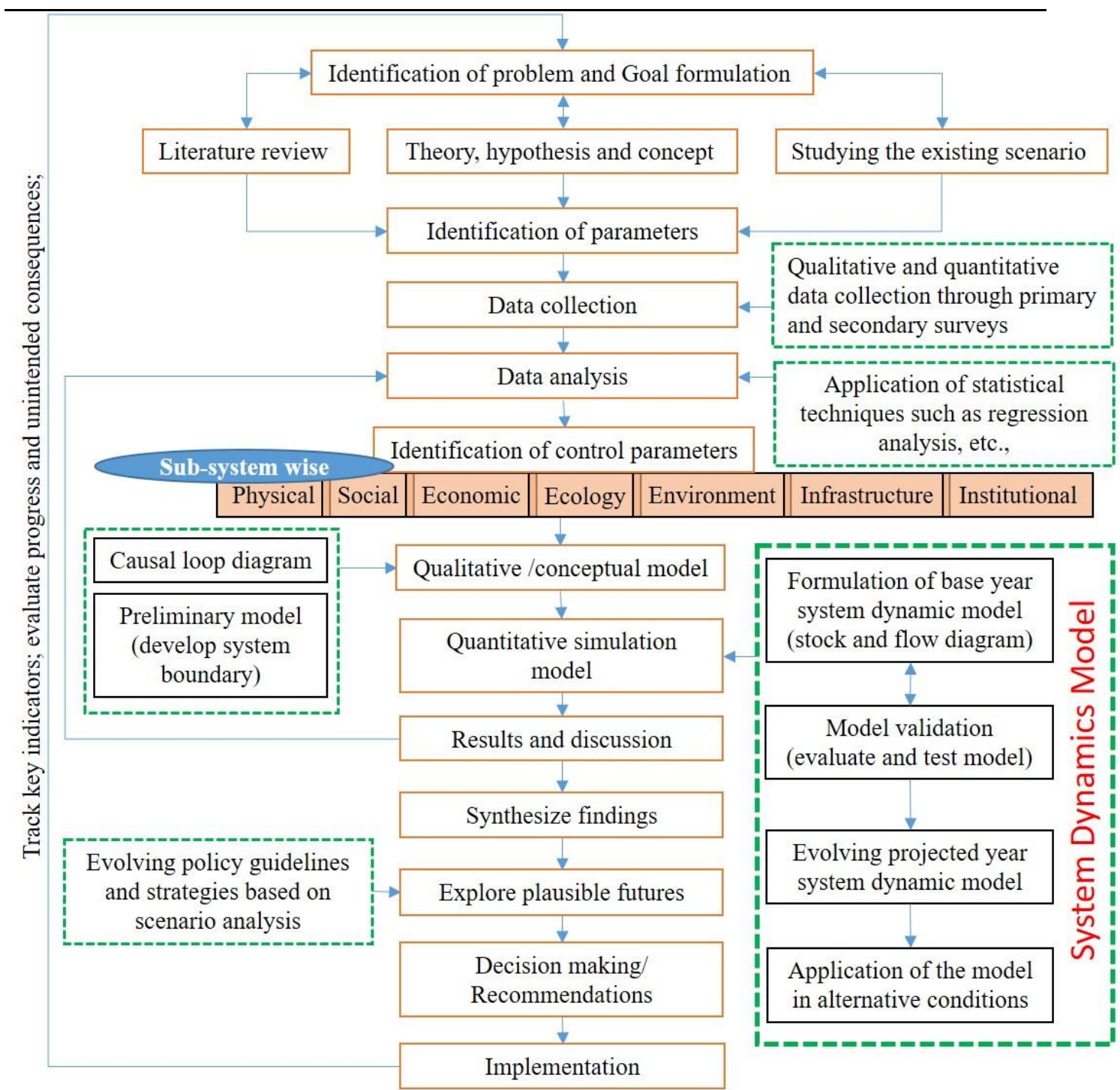

Figure 6: Framework for development plan formulation using system dynamics

\section{Conclusion}

The present paper studies literature on the role of system dynamics in evolving the sustainable development plan from a perspective of climate change and glacier melt that has not been covered by the existing reviews. Instead of focusing on the application of system dynamics technique in different project phases, the authors' goal was to understand the evolution of literature on this subject and its development according to dimensions of sustainability. The authors were able to successfully answer the research question by conducting an informetric analysis of literature and by classifying it based on the content analysis of 406 journal articles published between 2007 and 2018. The gaps and trends were identified accordingly. It is observed that the articles are largely concentrated on the three major pillars of sustainable development, such as environment, economic and social dimensions. Further, it is observed that publications on this subject registered an exponential growth, with $77.5 \%$ of the articles being published in the last five years. A total of 1308 authors were identified contributing for 406 published articles. As high as 60 articles are found from the Journal of cleaner production followed by sustainability with 52 articles, 
energy policy with 12 articles. Also, Elsevier publications accommodates for $34 \%$ of the total articles reviewed and is followed by Emerald, MDPI, Springer, Wiley, etc., The articles largely focused keywords (top 5) are socio-economic effects, sustainable development, environment factors, climate mitigation and government policies. Lastly, carried out the network analysis and cluster analysis of the top words used by the authors in the Keywords. Despite the comprehensive review performed in this research, the methodology followed by the authors has a few limitations. The Engineering village (COMPENDEX and INSPEC) was the only search engine used in the research. Furthermore, only peer-reviewed journal articles i.e., with a stronger methodological background were reviewed, while books and conference papers were disregarded. At last, the obtained results reflect the keyword selection, meaning that the articles that did not contain any of these keywords were not considered. However, the word selection was carefully addressed so that it included (nearly) all works on this subject. In summary, the main challenge and gap identified by the authors is that there is a lack of an Integrated planning approach considering the linkages between climate change, glacier melt, water resources and development planning. In order to address the aforementioned challenge, a framework for development plan of a region have been suggested in this paper. In conclusion, the climate change adaptation and mitigation decisions/interventions to achieve sustainable development at the regional scale includes, reducing sources of greenhouse gases or enhance the "sinks" that accumulate and store these gases; Stabilize greenhouse gas levels in a timeframe sufficient to allow ecosystems to adapt naturally to climate change; Energy efficiency; greater use of renewable energy; and longer growing seasons or increased yields in some regions to reduce the vulnerability to the harmful effects of climate change.

\section{Acknowledgement}

This work has used annotated bibliography from Ph.D. research works done by Dr. A. Salim, Dr. D.K. Das, Dr. S. K. Sonar, Dr. H. Zia, Dr. M.K. Chavan, Dr. S. Pipralia, Dr. R. Kumari, Dr. N. Kumar, Dr. T. Rawal, Dr. P. Nigam and Dr. N. Gupta under the supervision of one of the authors (Prof. V. Devadas) at the Department of Architecture and Planning, Indian Institute of Technology Roorkee. Authors thank the Indian Institute of Technology, Roorkee for providing necessary resources, such as Ph.D. theses, lab facilities, engineering village database for doing this study.

\section{References}

Arora, M. (2010) 'Estimation of Melt Contribution to Total Streamflow in River Bhagirathi and River DhauliGanga at Loharinag Pala and Tapovan Vishnugad Project Sites', Journal of Water Resource and Protection, 02(07), pp. 636-643. doi: 10.4236/jwarp.2010.27073.

Asian Development Bank (2014) India: Support for the Implementation of the National Water Mission by State Governments in India: Scoping Study for a National Water Use Asian Development Bank.

Azhoni, A., Jude, S. and Holman, I. (2018) 'Adapting to climate change by water management organisations: Enablers and barriers', Journal of Hydrology. The Author(s), 559, pp. 736-748. doi: 10.1016/j.jhydrol.2018.02.047.

Bajracharya, S. R., Shrestha, M. and Shrestha, A. B. (no date) 'Impact of Climate Change on Water resources and livelihood in the HKH region : Introduction ': doi: 10.13140/RG.2.1.1330.0082.

CDM (2011) Climate Change Handbook fo Regional Water Planning, U.S. Environmental Protection Agency, California Department of Water Resources, U.S. Army Corps of Engineers. 
Chandrappa, R., Kulshrestha, U. C. and Gupta, S. (2011) 'Coping with Climate Change', Agriculture, pp. 213-224. doi: 10.1007/978-3-642-19674-4.

Chen, Z. and Wei, S. (2014) Application of System Dynamics to Water Security Research, Water Resources Management. doi: 10.1007/s11269-013-0496-8.

Cox, W. E. (1987) The role of water in socio-economic development, United Nations Educational, Scientific and Cultural Organization (UNESCO). doi: 10.1017/CBO9781107415324.004.

Duethmann, D. et al. (2015) 'Attribution of streamflow trends in snow and glacier meltdominated catchments of the Tarim River, Central Asia', Water Resources Research, 51(6), pp. 4727-4750. doi: 10.1002/2014WR016716.

Fujita, K. and Sakai, A. (2014) 'Modelling runoff from a Himalayan debris-covered glacier', Hydrology and Earth System Sciences, 18(7), pp. 2679-2694. doi: 10.5194/hess-18-2679-2014.

Harender Raj Gautam, H. L. S. (2012) 'Environment and Rural Issues', Kurukshetra: A Journal on rural Development, 60(8), pp. 3-5.

IPCC (2014) Summary for Policymakers, Climate Change 2014: Synthesis Report. Contribution of Working Groups I, II and III to the Fifth Assessment Report of the Intergovernmental Panel on Climate Change. doi: 10.1017/СBO9781107415324.

Jansson, P., Hock, R. and Schneider, T. (2003) 'The concept of glacier storage: A review', Journal of Hydrology, 282(1-4), pp. 116-129. doi: 10.1016/S0022-1694(03)00258-0.

Kaltenborn, B. P., Nellemann, C. and Vistnes, I. I. (2010) High mountain glaciers and climate change - Challenges to human livelihoods and adaptation, United Nations Environment Programme. Available

at: http://www.grida.no/_res/site/file/publications/glacier/himalayareport_screen.pdf.

Kandlikar, M. and Sagar, A. (1999) 'Climate Change Science and Policy in India: an integrated assessment of North-South divide', Global Environmental Change, 9, pp. 119-138.

Khan, A. A. et al. (2015) 'The Himalayan cryosphere: A critical assessment and evaluation of glacial melt fraction in the Bhagirathi basin', Geoscience Frontiers. Elsevier Ltd. doi: 10.1016/j.gsf.2015.12.009.

Kumar, V., Singh, P. and Singh, V. (2007) 'Snow and glacier melt contribution in the Beas River at Pandoh Dam, Himachal Pradesh, India', Hydrological Sciences Journal, 52(2), pp. 376-388. doi: 10.1623/hysj.52.2.376.

Miller, J. D., Immerzeel, W. W. and Rees, G. (2012) 'Climate Change Impacts on Glacier Hydrology and River Discharge in the Hindu Kush - Himalayas A Synthesis of the Scientific Basis', Mountain Research and Development, 32(4), pp. 461-467. doi: 10.1659/MRD-JOURNAL-D-12-00027.1.

Miller, J., Stumm, D. and Stoffel, M. (2012) Glaciers, Snow melt and Runoff in the Himalayas Report on the outcomes of a Trans-Himalayan workshop held at ICIMOD in. Kathmandu, Nepal. Available at: http://www.euhighnoon.org/media/default.aspx/emma/org/10786702/Workshop_report_FINAL_050312.pdf.

Mittal, S., Tripathi, G. and Sethi, D. (2008) Development Strategy for the Hill Districts of Uttarakhand, Indian Council for Research on International Economic Relations.

Nepal, S., Flügel, W.-A. and Shrestha, A. B. (2014) 'Upstream-downstream linkages of hydrological processes in the Himalayan region', Ecological Processes, 3(1), pp. 1-16. doi: 10.1186/s13717014-0019-4.

Omani, N., Srinivasan, R. and Smith, P. K. (2016) 'Glacier mass balance simulation using SWAT distributed snow algorithm - Hydrological Sciences Journal -', 6667(August). doi: 10.1080/02626667.2016.1162907.

Panday, P. K. et al. (2014) 'Application and evaluation of a snowmelt runoff model in the Tamor 
River basin, Eastern Himalaya using a Markov Chain Monte Carlo (MCMC) data assimilation approach', Hydrological Processes, 28(21), pp. 5337-5353. doi: 10.1002/hyp.10005.

Prasad, A. K. et al. (2009) 'Melting of major Glaciers in the western Himalayas: Evidence of climatic changes from long term MSU derived tropospheric temperature trend (1979-2008)', Annales Geophysicae, 27(12), pp. 4505-4519. doi: 10.5194/angeo-27-4505-2009.

Prasch, M., Mauser, W. and Weber, M. (2013) 'Quantifying present and future glacier melt-water contribution to runoff in a central Himalayan river basin', Cryosphere, 7(3), pp. 889-904. doi: 10.5194/tc-7-889-2013.

Qiu, J., R. Zhao, S. Yang, and K. D. (2017) Informetrics: Theory, Methods and Applications. Springer Singapore.

Rahman, K. et al. (2015) 'An independent and combined effect analysis of land use and climate change in the upper Rhone River watershed, Switzerland', Applied Geography. Elsevier Ltd, 63, pp. 264-272. doi: 10.1016/j.apgeog.2015.06.021.

Rajesh Bhakar (2012) Center for Studies in Science Policy School of Social Sciences Jawaharlal Nehru University Research objective.

Santos, R. et al. (2019) 'Automation in Construction Informetric analysis and review of literature on the role of BIM in sustainable construction', Automation in Construction. Elsevier, 103(November 2018), pp. 221-234. doi: 10.1016/j.autcon.2019.02.022.

Sharma, B. R. and Sharma, D. (2008) 'Impact of Climate Change on Water Resources and Glacier Melt and Potential Adaptations for Indian Agriculture *', in Change, pp. 86-101.

Singh, B. R. and Singh, O. (2013) 'A Study About Realities of Climate Change: Glacier Melting and Growing Crises', Climate Change - Realities, Impacts Over Ice Cap, Sea Level and Risks.

Singh, M. and Pallavi, P. (2015) 'Reservoir induced impact on Agricultural patterns and Livelihood practices: A case study of Pratapnagar block in Tehri dam rim area', 5(8), pp. 1-8.

Singh, P. and Jain, S. K. (2003) 'Modelling of streamflow and its components for a large Himalayan basin with predominant snowmelt yields', Hydrological Sciences Journal, 48(2), pp. 257-276. doi: 10.1623/hysj.48.2.257.44693.

Sterman, J. (2000) Business dynamics: systems thinking and modelling for a complex world. McGraw-Hill, Boston.

Tadele, K. and Förch, G. (2007) 'Impact of land use/cover change on streamflow: the case of Hare River Watershed, Ethiopia', symposium (LARS), Arba Minch, Ethiopia, pp. 80-85.

Watts, G. et al. (2015) 'Climate change and water in the UK - past changes and future prospects', Progress in Physical Geography, 39(1), pp. 6-28. doi: 10.1177/0309133314542957.

Winz, I., Brierley, G. and Trowsdale, S. (2008) 'The Use of System Dynamics Simulation in Water Resources Management', Water Resources Management, 23(7), pp. 1301-1323. doi: 10.1007/s11269-008-9328-7.

Zeng, R. and Cai, X. (2014) 'Analyzing streamflow changes: Irrigation-enhanced interaction between aquifer and streamflow in the Republican River basin', Hydrology and Earth System Sciences, 18(2), pp. 493-502. doi: 10.5194/hess-18-493-2014. 